\title{
Keiretsu Shareholding Ties: \\ Antitrust Issues
}

\section{David Flath}

\section{Working Paper No. 70}

\author{
Professor David Flath \\ Department of Economics \\ North Carolina State University
}

Working Paper Series

Center on Japanese Economy and Business

Graduate School of Business

Columbia University

November 1992 
Novemeber 1992

\title{
KEIRETSU SHAREHOLDING TIES: ANTITRUST ISSUES
}

\author{
David Flath ${ }^{*}$
}

\begin{abstract}
$\underline{\text { Abstract }}$
Antitrust concern about keiretsu shareholding ties is misplaced and at odds with economic reasoning and with empirical investigation. Shareholding by suppliers in their customers assures the suppliers of rewards from their transaction-specific investments. Shareholding by customers in suppliers bonds the suppliers to cater more fully to the customers' interests. Shareholding by Japanese banks in the companies to which they lend resolves agency problems and lowers the costs of borrowing. Organization of firms into cross-shareholding groups magnifies the favorable effects of cross-shareholding by assuring that direct shareholding links give rise to indirect shareholding as well. To the extent that keiretsu shareholding ties impede U.S. exports to Japan it is because they lower the keiretsu members' transactions costs of trading with one another and not because they raise rivals' costs.
\end{abstract}

"Department of Economics, North Carolina State University, Raleigh, NC 27695-7506. Tel. (919)515-2472. 


\section{KEIRETSU SHAREHOLDING TIES: ANTITRUST ISSUES}

\section{Introduction}

In a 1957 Supreme Court ruling ${ }^{1}$ Du Pont was found to have violated antitrust laws for holding a 23\% stock interest in GM. GM was a customer of Du Pont. For instance in 1947 General Motors purchased $68 \%$ of its paint and 38\% of its fabric from Du Pont. Judge Brennan wrote that Du Pont's commanding position in sales of these products to GM was "promoted by its stock interest and was not gained solely on competitive merit".

Recent complaints about the Japanese business groups known as keiretsu have once again made an antitrust issue of shareholding ties between trading partners. At the nub of the complaints about the keiretsu is a belief that shareholding ties predispose firms to trade with one another on grounds besides "competitive merit", precisely as Justice Brennan claimed in the Du Pont-GM case. Keiretsu ties have facets besides interlocking shareholding, for instance monthly meetings of the company presidents, interlocking directorates, and in some instances a shared brand name (e.g. Mitsui, Sumitomo, etc.), but the share interlocks are the most pervasive, fundamental and direct source of any alignment of interests among group members. U.S. negotiators in the ongoing Japan-US trade talks have identified the keiretsu groups as a "structural impediment" to the sale of American products in Japan and as a remedy sought the application of Japan's antimonopoly laws to the keiretsu. The U.S. attorney general William Barr provoked a flap in February 1992 by suggesting in a television interview that U.S. antitrust laws might be applied extraterritorially to the keiretsu firms if their ties to one another

\footnotetext{
${ }^{1}$ United States v. E. I. Du Pont de Nemours \& Co., Supreme Court of the United States, 1957.
} 
can be shown to be impeding American exports to Japan. ${ }^{2}$

Evidence that keiretsu ties have exclusionary effects is hardly compelling. The strongest evidence has been advanced by Lawrence (1991), who demonstrates that import penetration into Japan is less in those industries for which keiretsu sales are more pervasive, controlling for the structure of inputs, sectoral demand, transportation cost, tariffs and producer concentration. But Lawrence's estimates also indicate that tariffs promote imports which we know to be false, as Saxonhouse argues in a critique published in conjunction with the Lawrence paper.

Saxonhouse further criticizes the Lawrence specification as poorly accounting for the effects of intersectoral factor price differences, non-traded goods, and heterogeneous products.

Lawrence identifies both "horizontal" keiretsu and "vertical" ones as retarding imports. These terms may be misleading as both refer to groupings of firms in different industries, firms that are possibly trading partners but are not rivals. By "horizontal" keiretsu Lawrence means the groups sometimes referred to as financial keiretsu (kinyu keiretsu), the successors of the pre-war zaibatsu that include many of the largest manufacturing and trading firms in Japan as well as the largest private commercial banks and insurance companies. Lawrence's "vertical" keiretsu are the groups sometimes referred to as enterprise groups (kigyo shudan). These include a large firm such as Toyota, Matsushita, or Mitsubishi Heavy Industries (each of which incidentally is also a member of a financial keiretsu) and its family of subsidiaries, subcontractors, and affiliates.

In this essay I shall focus on the financial keiretsu, Lawrence's "horizontal keiretsu", which are more likely than the ("vertical") enterprise groups to entail shareholding links between large

\footnotetext{
2"Antitrust Proposal Draws Opposition", The Washington Post, February 23, 1992, p. A9.
} 
corporations. It is certainly not transparent which firms belong to which keiretsu groups. A conservative definition of membership would include as members of a financial keiretsu only those firms represented at the monthly "presidents' club" meeting of the group. A more inclusive but somewhat ambiguous criterion would be to identify as members all the firms for which a financial institution of the presidents' club is the largest creditor. Lawrence's data source, Dodwell Marketing Consultants, tends towards this wider definition of keiretsu affiliation.

\section{Effects of Cross-Shareholding on Product Market Outcomes}

\subsection{Some preliminary considerations.}

In thinking about the likely effects of keiretsu share interlocks there are three points worth remembering. First, the share interlocks typical of the large manufacturing and trading firms that are members of the presidents' clubs of the six financial keiretsu--Mitsui, Mitsubishi, Sumitomo, Fuyo, Sanwa, and Dai-Ichi--are too small to confer any significant control over product market choices of the target firms. The usual range for such shareholding is from less than $1 \%$ to as much as $5 \%$, far below the $23 \%$ of GM stock held by Du Pont. Shareholding that confers a silent financial interest only can nevertheless have significant effects by altering the calculations of the firm that holds the shares. Additionally, there may be indirect or strategic effects that operate through other firms' reactions to the altered calculations of the shareholding firm.

Second, the keiretsu groups include firms in differing industries; the firms linked by keiretsu share interlocks possibly are trading partners but are not rivals. The complete-set 
principle (wan setto shugi) enunciated by Yoshikazu Miyazaki refers to the fact that each of the six keiretsu includes a city bank, trust bank, and insurance companies, as well as a general trading company and manufacturing companies in a spectrum of industries--one large firm from each different industry. Because keiretsu groups tend not to include firms in the same industry cartelization appears not to be the motive.

Third, shareholding by financial institutions including the large city banks accounts for more than half of the intra-group stockholding in the "financial keiretsu". Stockholding by a bank in the companies to which it lends is likely to have a rather different motivation than stockholding by a manufacturing or trading firm in one of its customers or in one of its input suppliers. We therefore need at least two models of keiretsu stockholding and perhaps three: one for stockholding by banks and the other one or two for stockholding that links trading partners, both stockholding in a customer and stockholding by a customer in a supplier. ${ }^{3}$

\subsection{Shareholding that Links Trading Partners ${ }^{4}$}

Commentators often allege that the members of the respective keiretsu presidents' clubs are predisposed to trade among themselves but the facts are hard to discern. A Japan Fair Trade Commission survey of the trading patterns among the keiretsu presidents' club members in 1981 (Kosei Torihiki Iinkai, 1983, Table 7, p. 24) found that $20 \%$ of the sales transactions of

\footnotetext{
${ }^{3}$ Sheard (1991) develops models of keiretsu cross-shareholding that are rather different from the ones I shall describe. Sheard emphasizes the advantages of reciprocal share interlocks in insulating firms from hostile takeovers, and in assuring a reserve of liquid assets.

${ }^{4}$ The analysis in this section is developed with mathematical preciseness in another manuscript (Flath, unpublished).
} 
manufacturing firms in the respective councils in excess of one million yen were to fellow members of the same councils. And $12 \%$ of purchase transactions in excess of one million yen by these manufacturing firms were from fellow members. Of course transactions may have been outside the presidents' club but still within the same keiretsu defined more broadly to include affiliates and subsidiaries of the respective presidents' club members. In any case, this evidence does indicate that there are significant trading ties among presidents' club members.

\subsubsection{Stockholding by Suppliers in Their Customers}

Shareholding by a supplier in a customer, as in Du Pont's shareholding in GM, confers special incentives on the supplier for investing in transaction specific assets. A supplier might rationally maintain a share interest in a customer to be sure of rewards for making customer specific investments: To the extent the rewards arise in part as dividends on the stock they are less subject to confiscation by the very firm in which the stock is held. I shall explain.

Where transaction specific investments establish a bilateral monopoly a "hold-up" problem is present (See Klein, Crawford, and Alchian, 1978, for an early statement of the hold-up problem). There are numerous models of bilateral monopoly. Let us take the simplest as an example: The seller sets a price and the buyer chooses a quantity. Under such a regime investments that lower the seller's costs confer rents on the buyer by inducing the seller to set a smaller product price. Cost reducing investments that are to the mutual advantage of buyer and selier may therefore necessitate a sidepayment by the buyer if they are to be in the self-interest of the seller. But the buyer has no incentive to fulfill a promised sidepayment once the investment is complete and, symmetrically, the seller has no incentive to carry out the 
investment if the sidepayment has already been made. That is, if neither's action can be made contingent on the action of the other each fears with good reason that its unilateral action will result in its being "held up" by the other. One way out of this impasse is for the seller to hold stock in the buyer. This enables the seller to more fully capture the joint gains to its cost reducing investments, for then it captures not only its share of the added rent as the seller but also its equity share in the added rent conferred on the buyer. Also ownership of the buyer's stock leads the seller to set a lower price which further enhances the joint profits. But will a seller hold stock in the buyer and not divest? If the stock market is efficient then the seller will not divest. The reason is that the seller's divestiture of any stock interest it holds in the buyer must then be at a price that anticipates fully the product market outcome. But with reduced equity interest in the buyer the seller will be led to set a higher product price which lowers the value of the buyer's stock; in the act of divesting its share interest in the buyer the seller imposes on itself a capital loss. Therefore it will not divest. The upshot is that if a sidepayment from buyer to seller takes the form not of cash but of the buyer's own stock the hold-up problem can be averted, because upon receipt of the "sidepayment" it becomes in the narrow self-interest of the seller to make the cost reducing investment.

That stockholding by suppliers in their customers can protect transaction specific investments has been widely recognized. For instance Pisano (1989) offers this as the rationale for stockholding by biotechnology firms in other such firms with which they are collaborating. However Pisano does not consider the stock market trading decisions of firms, though as sketched here the seller's decision to hold rather than divest its share interest in the customer is crucial to the argument. 
In the light of the above reasoning some details of the Du Pont-GM case that might have appeared to be inconsequential take on a new significance. Little noted at the time of the case is the fact that both the paint and fabric Du Pont was selling to GM were the result of patented processes and were specially suited for GM's uses. These products included "Fabricoid" artificial leather, "Pyraline" celluloid sheeting and "Duco" finish. By holding stock in GM, Du Pont was able to protect its automotive specific investments.

\subsubsection{Stockholding by Customers in Suppliers}

A firm might rationally acquire a silent interest in a supplier to indirectly assure the quality of the supplier's product. A customer that is also a stockholder is a patsy who buys a lot even if the price is high (because a portion of the profits that its patronage confers returns to it as a dividend). But precisely for this reason the supplier will refrain from cheating a stockholdercustomer lest it dump the stock and end the sweetheart deal. Again, I shall explain.

Where product quality can not be detected until after a trade is consummated the seller may be tempted to substitute products of lower quality than promised in order to realize a cost saving. In doing so the seller forgoes any future rents that are contingent on the buyer's trusting it to fulfill such promises but these rents may not be great enough to deter the seller from cheating.

In a bilateral monopoly in which the seller sets a price and the buyer chooses quantity, the buyer's holding of stock in the seller confers added rents on the seller, for a stockholding customer has less elastic demand than if it did not hold stock. Thus a stockholding customer is a more valuable customer whose trust the seller is inclined to prize more highly. This is 
particularly so because once cheated, a stockholding customer is likely to divest, further reducing the stream of rents to the seller. The reason that a stockholding customer has a credible threat to divest is that its capital loss on the sale of its shares is likely to be more than offset by the added rents that are conferred on it by the seller's reduced product price. Again the argument hinges on stock market efficiency. The buyer's divestiture of the seller's stock is at a price that correctly anticipates the smaller product price that the seller will set postdivestiture. But though the buyer's divestiture reduces the profits of the seller it likely does not reduce and may enhance the combined profits. ${ }^{5}$ In this case the buyer's capital loss from divestiture, which is merely a fraction of the seller's loss in profits, is more than offset by the buyer's own product market gains.

This argument has close parallels to the Klein and Leffler (1981) and Shapiro (1983) price premium for assuring quality argument. In the Klein-Leffler/Shapiro argument the seller unilaterally establishes a price premium and then conspicuously dissipates resources of equal present value to that of the premium stream to signal the premium's existence to buyers. In my argument, once the customer holds the seller's stock it becomes automatically in the seller's self-interest to raise price, so signalling the existence of a price premium stream is unnecessary and any costs of such signalling are avoided.

\footnotetext{
${ }^{5}$ If (1) the final demand (faced by the "buyer" in this bilateral monopoly example) has constant elasticity, (2) the seller's production technology exhibits constant returns to scale, (3) the buyer employs the seller's product in fixed proportions with other inputs, and (4) the seller owns no stock interest in the buyer, then the final price and output of the bilateral monopoly is the same whatever the buyer's stock interest in the seller. See Flath (unpublished) for a detailed explanation.
} 


\subsubsection{Relevance to the keiretsu}

As already discussed, the keiretsu presidents' club members are linked to one another by shareholding ties and also trade with one another. Is it possible to discern whether the shareholding links facilitate the trading in the ways just outlined? There are several observations that suggest this is the case. First, there is a tendency for firms that invest more intensively in research and development to hold larger equity positions in other members of their same presidents' clubs (Flath, unpublished) which is consistent with one motivation for the shareholding being to capture downstream rents due to cost reducing investment. Second, there is a further tendency for firms to hold larger equity positions in fellow club members that advertise less, invest less in R\&D, and which are growing slowly (Flath, unpublished) all of which is consistent with the quality assurance rationale for stockholding by a customer in a supplier: The prices and profits of sellers with lower growth prospects and which face more elastic demand (and therefore which advertise less intensively and invest in R\&D less intensively) are likely to be less sensitive to stockholding by customers, and stockholding by customers in such sellers must be to that extent greater to avert them from cheating.

Shareholding by banks comprises a substantial portion of keiretsu cross-shareholding and for that we require additional explanations to which I turn next.

\subsection{Stockholding by Banks}

\subsubsection{Banks and the financial keiretsu}

The six largest city banks are typically the largest debtholders in the companies that are 
members of their same keiretsu presidents' club. On average in 1980 the city bank of each respective presidents' club group held about $10 \%-20 \%$ of each manufacturing club member's debt, the trust bank 5\%-10\% and a life insurance company $1 \%-5 \%$. Most debt of most club members was held by financial institutions not affiliated with their same club.

Much of the shareholding in the keiretsu groups is shareholding by banks. Many commentators have argued that stockholding by Japanese banks in the companies to which they lend resolves agency problems and lowers the costs of financial intermediation. There are two important sources of these agency problems--asset substitution and information asymmetry. Stockholding by banks can reduce the costs of resolving or confronting these problems which are the transactions costs of borrowing. Two simple examples illustrate the problems and illustrate the manner in which bank stockholding mitigates the problems.

asset substitution $^{6}$

A borrower attaches the same zero value to states in which partial default occurs and to states of full default, but the lender clearly does prefer partial default to complete default. Investments that maximize the expected value of the firm but that risk partial default may therefore be passed over in favor of riskier projects. ${ }^{7}$ To put it a little differently, borrowers are not as averse to default as lenders would like them to be.

${ }^{6}$ For an early discussion of the asset substitution problem refer to Jensen and Meckling (1976).

${ }^{7}$ There is a symmetric distortion which would arise if lenders rather than borrowers chose investments. But because stockholders vote while debtholders do not, the manager is usually considered to be under the control of the stockholders. Or in other words, both the stockholders/borrowers and manager are agents of the debtholders/lenders. 
An example illustrates the problem. Suppose that debt commits the firm to the payment of interest $=\$ 50$ and that its managers must choose one of three projects each of which has two equally likely payoffs:

$\begin{array}{rrrrrr} & \text { state 1 } & \text { state 2 } & \text { NPV } & \begin{array}{l}\text { NPV to } \\ \text { stock- } \\ \text { holders }\end{array} & \begin{array}{l}\text { NPV to } \\ \text { debt- } \\ \text { holders }\end{array} \\ \text { project A } & \$ 100 & \$ 30 & \$ 65 & \$ 25 & \$ 40 \\ \text { project B } & 120 & 0 & 60 & 35 & 25 \\ \text { project C } & 50 & 50 & 50 & 0 & 50\end{array}$

The stockholders prefer project B. The debtholders prefer project C. Firm value is maximized by choosing A. Investors holding both debt and stock (not necessarily in equal proportions) will prefer the value maximizing project. If banks hold both stock and debt in companies it can therefore be mutually advantageous for other investors to defer to their judgement in evaluating projects.

\section{information asymmetry}

Loans must be acceptable to both borrower and lender based on their respective private information. The prudent lender will not rely on borrowers' truthful revelation of information that is damaging and will instead assume the worst. If this problem cannot be resolved then self financing by retention of earnings will displace both new equity issues and debt. This is the famous Myers "pecking order" theory (Myers and Majluf, 1984).

An example similar to the one used to illustrate the asset substitution problem may be 
helpful. Suppose here that firms are committed to particular real investments but that the firms are of two types. One is high risk and the other low risk. The manager of a firm knows his own firm's true characteristics but outsiders do not. If debt commits the firm to the payment of interest $=\$ 50$ then the debt of the high risk firm has a lower NPV than that of the low risk firm:

$\begin{array}{ccccc} & \text { state 1 } & \text { state 2 } & \text { NPV } & \begin{array}{c}\text { NPV of debt } \\ \text { that promises } \\ \text { interest }=\$ 50\end{array} \\ \begin{array}{c}\text { prob }=.5 \\ \text { high risk } \\ \text { firm }\end{array} & \$ 100 & \$ 0 & \$ 50 & \$ 25 \\ \begin{array}{c}\text { low risk } \\ \text { firm }\end{array} & 50 & 50 & 50 & 50\end{array}$

If the low risk firm is unable to differentiate itself from the high risk firm then it can only sell its debt at the $\$ 25$ that is the NPV of debt in the high risk firm. On these terms the low risk firm cannot profitably finance its investments. Notice however that a combination of debt and equity has the same NPV in both firms. Additionally banks that own stock will have access to inside information that enables them to distinguish the true risk of debt. Notice also in this example that it is the low risk firms that gain from these aspects of bank stockholding, not the high risk firms. Can this be why not all firms in Japan form main bank relationships or become members of financial keiretsu?

Also, any mechanism that automatically transfers wealth from stockholders to debtholders in event of default raises the value of debt in the high risk firm, narrowing the difference in value of debt between the two. 


\subsubsection{Stockholding by Banks in the U.S. and in Japan.}

Shareholding by lenders including banks is effective at resolving the agency problems of borrowing. By holding shares, lenders both gain inside information about the firms's dealings and also gain the power to act on the information. And as detailed above banks that hold both stock and debt have efficient incentives in evaluating the firm's real investments. Banks that hold stock can accurately assess risk and can forestall asset substitution. Researchers have accumulated much evidence that shareholding by banks in Japan is precisely for these reasons and that only regulatory constraints have deterred American banks from similar practices.

In the US, the Glass-Steagall Law of 1933 prevents shareholding by banks but with one important exception: Banks may assume ownership of stock in firms that default on their loans. Banks take advantage of this loophole. A study by Gilson (1990) details the extensive equityholdings assumed by banks upon loan default. Also LBO organizations (which are not banks and therefore not subject to Glass-Steagall) have reorganized a number of large US corporations as limited partnerships in which they hold both equity and debt (Jensen, 1989). So in the limited instances where shareholding by lenders is allowed in the US we do in fact observe it.

More generally, bankruptcy laws in the US can be relied upon to transfer control of defaulting firms to creditors in the event private negotiations fail to accomplish the same. As a result, if asset substitution or misrepresentation ends in default, managers expect to be displaced and shareholders expect to be penalized. The way bankruptcy is treated in the US legal system assures that managers and shareholders of defaulting firms will bear a cost.

Studies have shown that the direct costs of bankruptcy are small in relation to firm value, 
less than $10 \%$ of market value at the time of default. Indirect costs may be large but are very hard to estimate. But not all costs of bankruptcy to stockholders reduce firm value. This is because costs of default borne by stockholders or managers are partly transfers to debtholders.

One way of describing the agency problem of debt is that borrowers are not as averse to default as lenders would like. Bankruptcy costs and wealth transfers to debtholders that result from bankruptcy or default settlements reduce agency problems by making default more painful for borrowers. Shareholding by banks in Japan accomplishes what the threat of bankruptcy does in the US. It forestalls asset substitution and opportunism. Perhaps the keiretsu evolved because the Japanese legal system was in some sense less adequate for this purpose than is that of the US. Alternatively, the absence of a Glass-Steagall type prohibition on bank shareholding may have allowed arrangements in Japan that would also be superior in the US but that are illegal there. If this is so then the costs of regulatory distortion in the US may be large.

Banks' shareholding in Japan is limited by the antimonopoly laws and these limits have recently been tightened. Before 1987 banks could legally hold no more than $10 \%$ of the shares in any one company. Now the limit has been lowered to 5\%. It is ironic that these regulations should be strengthened just as the advantages of bank shareholding are being recognized.

Researchers are accumulating evidence that shows shareholding by keiretsu banks has indeed lowered the costs of debt, removed liquidity constraints, and promoted greater borrowing. The evidence is that companies with close ties to keiretsu banks are less liquidity constrained than other companies, controlling for real investment prospects (Hoshi, Kashyap, and Scharfstein, 1991). Keiretsu banks hold more stock in companies that are prone to agency 
problems than in others, and borrowing by keiretsu companies is not constrained by agency problems as it is in the US (Prowse, 1990).

In the US, companies with high R\&D expenses, high growth, intangible assets and the like have lower debt to equity ratios (Titman and Wessels, 1988). In Japan this appears to be less so based on reduced form estimates reported by Prowse (1990). The interpretation is that because Japanese banks hold stock in firms that are prone to agency problems, such firms are less impeded in borrowing in Japan than in the US.

I have attempted estimation of structural equations explaining debt to asset ratios and stockholding by largest lenders in Japanese corporations including members of the financial keiretsu "presidents' clubs (Flath, forthcoming-b). These estimates add further weight to arguments that stockholding by keiretsu banks lowers the costs of their financial intermediation. The estimates indicate that largest debtholders in keiretsu presidents' club firms hold more stock if the firms borrow heavily or have weaker collateral, greater prospects of growth, or high levels of spending on research and development or on advertising, precisely the companies most prone to the agency problems of debt which stockholding by a main bank can help resolve. The estimates further demonstrate that keiretsu presidents' club companies in which debtholders hold more stock borrow more, ceteris paribus. I find this effect is not significantly stronger for largest debtholders than for lesser ones, and perhaps the meaning of "main bank" needs to be reexamined in this light. Commentators on Japanese corporate finance have often suggested that each keiretsu firm has a "main bank" with special responsibilities for monitoring (Hodder and Tshoegl, 1985; Sheard, 1989). Perhaps instead of being a "delegated monitor" the largest debtholders, along with smaller debtholders in the same firms, are joint contributors 
to a monitoring effort which is a local public good.

\section{Multifirm Groups Versus Bilateral Alliances}

The rationales for cross-shareholding discussed here have pertained to pairs of firms that are trading partners or a creditor and its client. Why then do the shareholding ties between Japanese firms align the firms into groups? Alignment of firms into groups assures that whatever direct shareholding ties are formed between pairs of firms will also result in the maximum indirect shareholding. Indirect shareholding (where company A owns stock in B and B owns stock in C) clearly has the same beneficial effects as direct shareholding, including the effects which I have described here. In other words, indirect shareholding confers spillover benefits on share-interlocked multifirm groups. Other commentators have recognized spillovers or externalities as essential to any advantages of multifirm groups but have attempted to discover such spillovers either in advertising (Hadley, 1970), or research and development efforts (Goto, 1982).

In another piece I have proposed a measure of indirect shareholding and computed it for the presidents' club firms of the six keiretsu. Flath (forthcoming-a). According to these computations, indirect shareholding in the six keiretsu, is about one fourth as great in magnitude as direct shareholding, which is arguably great enough to be the rationale for alignment of cross-shareholding firms into groups.

\section{Conclusions}

Keiretsu shareholding ties are prominent among the business practices or institutions that 
appear to be somewhat peculiar to Japan and which challenge economists to modify existing models or come up with new ones. The many peculiar practices that have been the bases of U.S. antitrust cases over the years have posed similar challenges. Seemingly anomalous practices have repeatedly been at first branded as cartel devices or stratagems for securing or protecting monopoly. This was true for tie-in sales, exclusive dealing stipulations, customer restrictions, resale price maintenance, delivered pricing systems and much else besides. But in each instance economic reasoning, aided and supported by careful investigation, has ultimately demonstrated that often the practices in question resolve problems in transacting or in some fashion promote an efficient organization of economic activity.

Keiretsu shareholding ties have been branded as anticompetitive, hostile to free trade, and supportive of insularity and inefficiency. Economic reasoning and empirical observation as discussed here paint a quite different picture. Stockholding that links trading partners resolves problems either by assuring the supplier of rewards from transaction specific investments or by bonding the supplier to cater more fully to the customer's interests. Stockholding by a bank in its customers confers efficient incentives on the bank to monitor the customers' choices and is a vehicle for assuring truthful revelation of information to the bank. Antimonopoly laws of Japan have recently been amended to lower the legal limit of bank stockholding in any company from $10 \%$ to $5 \%$. Complaints by U.S. trade negotiators and others threaten to provoke antitrust action against trading partners linked by shareholding ties. These developments are at the least disturbing. The economic models I have described here afford ample reasons to doubt the wisdom or appropriateness of antitrust action against keiretsu shareholding ties. 


\section{REFERENCES}

Flath, David (forthcoming-a), "Indirect Shareholding Within Japan's Business Groups," Economics Letters.

(forthcoming-b), "Shareholding in the Keiretsu, Japan's Financial Groups," The Review of Economics and Statistics.

(unpublished), "The Keiretsu Puzzle".

Gilson, Stuart (1990), "Bankruptcy, Boards, Banks, and Blockholders: Evidence on Changes in Corporate Ownership and Control When Firms Default," Journal of Financial Economics, vol. 27 , no.2, pp.

Goto, Akira (1982), "Business groups in a Market Economy," European Economic Review, vol. 19, pp. 53-70.

Hadley, Eleanor (1970), Antitrust in Japan, Princeton: Princeton University Press.

Hodder, James E. and Adrian E. Tschoegl (1985), "Some Aspects of Japanese Corporate Finance," Journal of Financial and Quantitative Analysis, vol. 20, no. 2, pp. 173-191.

Hoshi, Takeo, Anil Kashyap and David Scharfstein (1991), "Corporate Structure, Liquidity, and Investment: Evidence from Japanese Panel Data," Quarterly Journal of Economics, vol. 106, no. 1, pp. 33-65.

Jensen, Michael C. (1989), "Eclipse of the Public Corporation," Harvard Business Review, vol. 5, pp. 61-75.

and William H. Meckling (1976), "Theory of the Firm: Managerial Behavior, Agency Costs and Ownership Structure," Journal of Financial Economics, vol. 3, no. 4, pp. 305-360.

Klein, Benjamin, Robert Crawford and Armen Alchian (1978), "Vertical Integration, Appropriable rents and the Competitive Contracting Process," The Journal of Law and Economics, vol. 84, pp. 297-326.

Klein, Benjamin and Keith Leffler (1981), "The Role of Market Forces in Assuring Contractual Performance," Journal of Political Economy, vol. 81, pp. 615-641.

Kosei torihiki iinkai jimukyoku, keizai-bu jigyo-ka (executive office of the fair trade commission of Japan, enterprise section, economic division) (1983), kigyo shudan no jitai ni tsuite (concerning the state of business groups) Kosei Torihiki, no. 394 (Aug.), pp. 20-24. 
Lawrence, Robert Z. (1991), "Efficient or Exclusionist? The Import Behavior of Japanese Corporate Groups," Brookings Papers on Economic Activity, 1, pp. 311-341.

Myers, Stewart C. and Nicholas S. Majluf (1984), "Corporate Financing and Investment Decisions When Firms Have Information that Investors Do Not Have," Journal of Financial Economics, vol. 13 , pp. 187-221.

Pisano, Gary P. (1989), "Using Equity Participation to Support Exchange: Evidence From the Biotechnology Industry," Journal of Law, Economics, and Organization, vol. 1, no. 5 pp. 109-126.

Prowse, Stephen D. (1990) "Institutional Investment Patterns and Corporate Financial Behavior in the U.S. and Japan," Journal of Financial Economics, vol. 27, no. 1, pp. 43-66.

Shapiro, Carl (1983), "Premiums for High Quality Products as Rents to Reputation," Quarterly Journal of Economics, vol. 98, pp. 659-680.

Sheard, Paul (1989), "The Main Bank System and Corporate Monitoring and Control in Japan," Journal of Economic Behavior and Organization, 11, pp. 399-422.

(1991), "The Economics of Interlocking Shareholding in Japan", Ricerche Economiche, vol. 14 (April-September), 2-3, pp. 421-448.

Titman, Sheridan and Roberto Wessels (1988), "The Determinants of Capital Structure Choice," Journal of Finance, vol. 43, pp. 1-19. 